\title{
TRADISI MEMBANGUN RUMAH DALAM KAJIAN KEARIFAN LOKAL (STUDI KASUS PADA masYaRAKAT ADAT KAMPUNG DUKUH)
}

\author{
THE TRADITION OF BUILD A HOUSE IN STUDY OF LOCAL WISDOM \\ (A CASE STUDY IN TRADITIONAL SOCIETY OF KAMPUNG DUKUH)
}

\author{
Rosyadi \\ Balai Pelestarian Nilai Budaya (BPNB) Bandung \\ Jalan Cinambo No. 136 Ujungberung - Bandung \\ ochadroki@yahoo.com
}

\begin{abstract}
Abstrak
Keberadaan masyarakat adat di tengah arus modernisasi dan globalisasi dewasa ini oleh sementara orang dipandang sebagai suatu hal yang unik dan janggal. Di tengah arus globalisasi, di mana orang sibuk dengan konsep-konsep dan pemikiran modern, masyarakat adat berusaha untuk tetap melaksanakan dan memelihara tradisinya. Melalui kajian-kajian antropologis terungkap bahwa tradisi-tradisi yang dikukuhi masyarakat adat tersebut ternyata sarat dengan nilai-nilai kearifan lokal, khususnya di dalam konteks hubungan manusia dengan ligkungannya, baik lingkungan alam, sosial, dan lingkungan budaya. Hal inilah yang melatarbelakangi penulis untuk melakukan penelitian ini. Melalui penelitian kualitatif dengan menggunakan metode deskriptif, penulis memaparkan berbagai fenomena alam, sosial dan budaya, apa yang dialami, diketahui, dilihat, dirasakan, dan dipikirkan oleh masyarakat adat Kampung Dukuh terhadap fenomenafenomena alam dan kondisi geografis yang mereka hadapi sehari-hari. Fenomena-fenomena alam dan budaya ini diinterpretasikan dan kemudian melahirkan tradisi yang sarat dengan kearifan lokal. Tradisi ini juga mewarnai aktivitas membangun rumah di kalangan masyarakat Kampung Dukuh, mulai dari penggunaan bahan, ritual-ritual, dan pantangan-pantangan adat.
\end{abstract}

Kata kunci: masyarakat adat, tradisi, kearifan lokal, arsitektur tradisional.

\section{Abstract}

The existence of indigenous peoples in the midst of modernization and globalization recently viewed as a unique and awkward by some people. In the midst of globalization, where people are busy with the modern concepts and ideas, indigenous people seek to continue thetraditions implementation and maintaining. Through anthropological studies revealed that the traditions of the indigenous peoples turns loaded with the values of local wisdom, particularly in the context of human relationships with environment, natural environment, social and cultural environment. Those phenomena are the background to conduct this research. By employing a qualitative study using descriptive method, the author describes the various natural phenomena, social and cultural;also,what thing is experienced, known, seen, felt, and thought by the traditional villagers of KampungDuku toward natural phenomena and geographical conditions that they face daily. Natural phenomena and culture is interpreted and subsequently deliver to a tradition which is loaded with local knowledge. This tradition also colorthe activity of homes buildingin the community of KampungDukuh, ranging from the use of materials, rituals, taboos and customs.

Keywords: Traditional village, traditions, local wisdoms, traditional architecture. 


\section{A. PENDAHULUAN}

$\begin{array}{lr}\text { Permasalahan lingkungan } & \text { hidup } \\ \text { berkaitan erat dengan } & \begin{array}{r}\text { konsep } \\ \text { pembangunan berkelanjutan, yaitu }\end{array}\end{array}$ pembangunan yang dapat memenuhi kebutuhan generasi sekarang tanpa mengorbankan generasi yang akan datang. Dalam Undang-undang Nomor 4 Tahun 1982, disebutkan bahwa : "Lingkungan hidup Indonesia yang dikaruniai oleh Allah Yang Maha Esa kepada bangsa dan rakyat Indonesia merupakan rahmat daripada-Nya dan wajib dikembangkan dan dilestarikan kemampuannya agar dapat tetap menjadi sumber dan penunjang hidup bagi bangsa dan rakyat Indonesia serta makhluk lainnya, demi kelangsungan dan kualitas hidup itu sendiri."

Undang-undang tersebut memosisikan lingkungan alam bukan hanya sekadar sebagai objek yang harus digunakan untuk memenuhi kebutuhan hidup manusia (human centris), melainkan ia juga harus dipelihara, ditata, dan dijaga kelestariannya (eco centris), agar kualitasnya tetap terjaga dan dapat tetap memenuhi kebutuhan hidup manusia.

Sementara itu, di tengah-tengah kegiatan pengeksploitasian lingkungan alam yang banyak dilakukan oleh "orangorang yang sudah maju" dengan menggunakan peralatan dan teknologi yang serba canggih, terdapat kelompokkelompok masyarakat atau komunitaskomunitas yang dengan pengetahuan lokal dan pranata-pranata tradisionalnya yang serba bersahaja mampu melestarikan lingkungan hidupnya. Komunitas masyarakat ini memperlakukan lingkungan alamnya dengan sangat arif. Kearifan mereka dalam meperlakukan lingkungan alam sudah barang tentu berkaitan erat dengan sistem nilai budaya yang mereka miliki. Komunitas-komunitas masyarakat ini lazim disebut sebagai komunitas adat, atau masyarakat adat.

Persoalan-persoalan eksistensi dan pemberdayaan masyarakat adat ini, telah lama menjadi sorotan dari berbagai pihak, baik pemerintah, lembaga-lembaga penelitian, lembaga-lembaga swadaya masyarakat, maupun lembaga-lembaga pembangunan nasional dan internasional. Menurut Tim Riset Pusakayang di-upload dalam(http://www.scribd.com/doc/361058 58/Riset-Hak-Masyarakat-Adat-Kasus-

Kasepuhan-Naskah-Final), diskursus masyarakat adat di Indonesia mulai muncul pada akhir periode 1980-an dan mulai menemukan momentumnya setelah EarthSummit atau KTT Bumi di Rio de Janeiro 1992.

Pada akhir 1980-an dan awal 1990an, kelompok-kelompok gerakan lingkungan dan HAM di Indonesia dan gerakan indigenous peoples di dunia internasional, mengusung istilah indigenous peoples yang dapat dipadankan dengan istilah 'masyarakat adat'. Istilah ini lebih mengakomodir dimensi kultural dan religius kelompok masyarakat yang dimaksud dan tidak mempersempitnya menjadi sekadar sebuah entitas hukum belaka.

José Martinez Cobo, seorang special raporteur yang ditunjuk oleh The United Nations Sub-Commission on Prevention of Discrimination and Protection of Minorities, dalam (Barnes, Gray and Kingsbury 1995: 26) merumuskan definisi indigenous peoples. Ada lima persoalan penting yang menjadi sorotan dalam definisi Cobo, yaitu:

1) Self-definition atau yang kemudian lebih mengemuka sebagai selfidentification, yaitu otonomi dalam mendefinisikan diri sendiri. Hal ini merupakan respon terhadap berbagai pendefinisian yang selama ini dilekatkan oleh pihak luar (dominant sector of society) terhadap diri mereka;

2) Historical continuity atau kesinambungan sejarah masa lampau sejak sebelum masa pendudukan oleh penjajah dengan keberadaan mereka sekarang ini;

3) Non-dominance sector of society, atau merupakan kelompok masyarakat yang tidak dominan dalam keseluruhan masyarakat bangsa; 
4) Ancestral territories atau wilayah yang diidentifikasi sebagai warisan leluhur atau nenek moyang dari kelompok tersebut; dan

5) Ethnic identity atau adanya pertalian etnis dalam kelompok masyarakat tersebut.

Seorang antropolog Indonesia, Abdul Latif, dalam sebuah makalahnya (2011) mendefinisikan masyarakat adat sebagai: kelompok masyarakat yang hidup dalam suatu wilayah geografis tertentu dalam kurun waktu yang relatif lama, terikat pada tradisi dan adat istiadat yang diwarisi dari leluhurnya, di antara para warganya satu sama lain terikat dalam hubungan kekerabatan. Pada umumnya mereka memiliki lembaga adat yang dipimpin oleh seorang ketua adat. Kepemimpinan ketua adat biasanya diwariskan secara turun-temurun, atau melalui ketentuan adat tertentu. Adapun yang dimaksud dengan lingkungan geografis adalah lingkungan alam di mana mereka hidup. Komunitas adat di Jawa Barat pada umumnya hidup di pedalaman, atau daerah pegunungan. Mereka mengandalkan hidupnya dari sektor pertanian, yaitu bersawah, berladang, dan berkebun.

Ade Makmur K. (2009), dalam sebuah makalahnya yang berjudul "Keberadaan Masyarakat Adat di Tengah Arus Modernisasi" menjelaskan, bahwa masyarakat adat atau oleh PBB disebut Indigenous Peoples, adalah pewaris dan pelaksana kebudayaan yang unik dan bentuk-bentuk hubungan dengan sesama manusia dan lingkungan, dengan mempertahankan sifat-sifat sosial, ekonomi dan politiknya yang berbeda dengan masyarakat pada umumnya di mana mereka tinggal. Merujuk pada definisi masyarakat adat oleh PBB tersebut, dalam konteks Indonesia setidaknya dikenal tiga kategori masyarakat adat, yaitu:

- Kelompok sosial yang terikat oleh tradisi, namun tidak terikat oleh kesatuan tempat tinggal yang sama.
- Kelompok sosial yang terikat oleh tradisi dan masih mengamalkan ketentuan leluhur, tetapi diberi kelonggaran memilih kesatuan tempat tinggal.

- Kelompok sosial yang terikat, dan menjalankan tradisi leluhur dengan ketat, serta terikat oleh kesatuan tempat tinggal yang sama dalam kelompok-kelompok yang kecil.

Dari ketiga kategori tersebut, kategori kesatu dan kedua lebih dikenal sebagai masyarakat tradisional dan kategori ketiga dikenal sebagai masyarakat adat. Adapun sebutan yang umum bagi mereka yang termasuk kategori tiga, dikenal dengan pelbagai istilah: seperti orang gunung (highlanders), orang asli (aborigines), orang hutan (forest people), pribumi (natives), dan masyarakat terasing (komunitas adat terpencil).

Masyarakat adat di Jawa Barat pada umumnya tinggal berkelompok di dalam suatu wilayah geografis di daerah pedalaman atau daerah pegunungan, dan mereka mengandalkan hidupnya dari sektor pertanian, yaitu bersawah, berladang, dan berkebun. Kehidupan mereka sangat erat dengan kebudayaan lokal. Mereka merupakan salah satu pendukung kebudayaan lokal, bahkan dapat dipandang sebagai benteng terakhir pengusung kebudayaan lokal di Indonesia. Keberadaan mereka yang tersebar di seluruh Indonesia memiliki potensi yang sangat besar dalam membangun kebudayaan Indonesia. Oleh karena itu, perhatian yang lebih serius perlu diberikan agar keberadaan mereka terlindungi dan mereka mendapat ruang untuk melangsungkan kehidupannya dan melangsungkan tradisinya, serta memberdayakan dirinya agar dapat meningkatkan kesejahteraan hidupnya.

\section{B. METODE PENELITIAN}

Penelitian ini bersifat deskriptif dengan pendekatan kualitatif. Masri Singarimbun (1981: 4) menjelaskan, bahwa metode deskriptif memiliki dua 
tujuan; pertama, mengetahui perkembangan sarana fisik tertentu atau aspek fenomena sosial tertentu; kedua adalah menggambarkan secara terperinci fenomena sosial tertentu. Dengan penelitian deskriptif ini diharapkan analisis penelitian mencakup keberadaan fenomena sosial secara lugas dan terperinci.

Sesuai dengan jenis penelitiannya yang bersifat kualitatif, maka datanya pun adalah data kualitatif, berupa rangkaian kata-kata atau kalimat tuturan para informan. Data primer yang bersifat kualitatif didapatkan melalui dua cara, yaitu wawancara mendalam (depth interview) dan pengamatan (observasi).

Wawancara dilakukan dengan informan terpilih guna mendapatkan data dan informasi dari sumber pertama. Wawancara dilakukan dengan informan pangkal atau informan kunci (key informan) dengan menggunakan pedoman wawancara (interview gauide), yang pertanyaan-pertanyaannya bersifat terbuka. Artinya, informan diberi keleluasaan untuk menyampaikan pendapat-pendapatnya. Penggunaan informan pangkal atau informan kunci adalah untuk penyusunan sample yang representatif dari orang-orang yang akan diwawancarai.

Pemilihan dan penentuan informan dilakukan secara berantai. Caranya adalah pertama-tama ditentukan informan kunci, kemudian untuk menentukan informan berikutnya berdasarkan petunjuk dari informan pertama. Demikian seterusnya hingga diperoleh sejumlah informan yang dirasa cukup untuk menjaring seluruh data yang diperlukan bagi penelitian ini. Teknik sampling ini oleh Bagdan dan Wilken (1986: 66) disebut sebagai teknik bola salju (snowball technic).

Unit analisis yang digunakan dalam penelitian ini adalah tokoh masyarakat dan warga Kampung Dukuh yang mengetahui aturan mendirikan rumah. Adapun teknik pengamatan atau observasi dilakukan guna menjaring data yang tidak dapat diungkap melalui wawancara. Selain kedua teknik pengumpulan data tersebut, juga dilakukan studi pustaka guna mendapatkan data dari sumber-sumber tertulis (data sekunder).

Berikutnya, data dianalisis dengan metode analisis kualitatif. Analisis kualitatif pada dasarnya adalah interpretasi data melalui tiga tahapan kegiatan yang berjalan secara simultan, yakni reduksi data, penyajian data, dan penarikan kesimpulan atau verifikasi.

Lokasi penelitian dilaksanakan di Kampung Dukuh, yang secara administratif masuk dalam kawasan Rukun Tetangga (RT) 33, Rukun Warga (RW) 35, Rukun Kampung (RK) 5 atau biasa disebut Kapunduhan Ciroyom, Desa Cijambe, Kecamatan Cikelet, Kabupaten Garut, Provinsi Jawa Barat.

Adapun tujuan yang ingin dicapai melalui penelitian ini adalah:

- Menggali dan memahami aturan mendirikan rumah dan makna yang terkandung dalam setiap unsurunsurnya.

- Mengidentifikasi perubahan-perubahan yang terjadi dalam hal aturan-aturan adat yang berkaitan dengan tempat tinggal, aturan membuat bangunan dan penggunaan lahan.

- Mengetahui faktor apa saja yang bisa menyebabkan perubahan.

\section{HASIL DAN BAHASAN}

1. Gambaran Umum Kampung Dukuh

Kampung Dukuh termasuk dalam

kawasan Desa Cijambe, Kecamatan Cikelet, Kabupaten Garut, Jawa Barat. Jarak Kampung Dukuh dari Desa Cijambe kurang lebih $1,5 \mathrm{~km}$, sedangkan dari pusat kota kurang lebih $101 \mathrm{~km}$. Untuk mencapai lokasi Kampung Dukuh bisa ditempuh dengan kendaraan pribadi maupun kendaraan umum sampai Kecamatan Cikelet, kemudian dilanjutkan dengan jasa angkutan ojeg sampai lokasi yang jaraknya kurang lebih $9 \mathrm{~km}$.

Luas keseluruhan Kampung Dukuh adalah 10 ha, terdiri atas: Dukuh Dalam yang biasa juga disebut Dukuh Tonggoh (Dukuh Atas) 1ha; Dukuh Luar, biasa juga 
disebut Dukuh Landeuh (Dukuh Bawah) seluas 7 ha dan sisanya merupakan lahan kosong atau lahan produksi. Di dalam Kampung Dukuh terdapat juga area yang disebut dengan wilayah karomah (keramat), yaitu tempat dimakamkannya Syekh Abdul Jalil, yang dipandang sebagai karuhun (leluhur) masyarakat Kampung Dukuh. Selain itu juga terdapat tempat pemakaman umum yang diperuntukkan bagi warga Kampung Dukuh, dan makam dari keturunan kuncen Kampung Dukuh yang letaknya terpisah dari area pemakaman umum. Sudah menjadi ketentuan bahwa di wilayah karomah tidak diperbolehkan mendirikan bangunan apa pun. Lahannya pun tidak boleh digunakan sebagai lahan garapan. Jadi, secara keseluruhan Kampung Dukuh dibagi menjadi tiga bagian, yaitu Kampung Dukuh Dalam, Kampung Dukuh Luar dan Karomah.

Kampung Dukuh terletak pada ketinggian $390 \mathrm{~m}$ di atas permukaan laut dengan suhu rata-rata $28^{\circ} \mathrm{C}$ dan letak astronomis pada garis $7^{\circ}-8^{\circ}$ Lintang Selatan, $7^{\circ}-108^{\circ}$ Bujur Timur. Udara di Kampung Dukuh tidak begitu panas dan dipengaruhi hutan lebat di sebelah utara kampung yang saat ini dikuasai oleh PT Perhutani. Letak kampungnya sendiri berada di tanah dengan topografi yang miring, dekat lereng Gunung Dukuh dan terpencil dari kampung-kampung lainnya dalam satu desa. Adapun yang menjadi batas-batas administratif Kampung Dukuh adalah:

- sebelah utara berbatasan dengan Kampung Sukadana;

- sebelah selatan berbatasan dengan Kampung Cibalagung;

- sebelah timur berbatasan dengan Kampung Rancaekek;

- sebelah barat berbatasan dengan Kampung Barujaya.

Ditinjau dari hak kepemilikan tanah, Kawasan Kampung Dukuh merupakan tanah ulayat. Artinya, lahan di kawasan Kampung Dukuh merupakan tanah adat yang kepemilikan dan penggunaannya diatur secara adat. Menurut fungsinya, lahan di Kampung Dukuh terbagi ke dalam:

a. Tanah karomah, yaitu lahan yang berada di dalam kawasan Dukuh Dalam yang dibatasi oleh pagar. Di dalam kawasan tanah karomah ini terdapat makam karomah yaitu kawasan tempat dimakamkannya Syekh Abdul Jalil yang merupakan pendiri kampung Dukuh. Kawasan ini terlarang bagi warga untuk memasukinya.

b. Tanah awisan, atau disebut juga tanah titipan, merupakan wilayah yang diperuntukkan bagi tempat pemukiman warga Dukuh berdasarkan nama awisan tersebut. Di kawasan Kampung Dukuh terdapat beberapa tanah awisan, yaitu awisan Sukapura, awisan Arab, awisan Sumedang, awisan Bangkelung dan awisan Dukuh. Awisan yang telah dijadikan tempat pemukiman warga adalah awisan Dukuh, Sukapura dan awisan Bangkelung. Awisan ini tidak dapat sembarangan dipakai sebagai lahan pemukiman, karena awisan ini diperuntukkan bagi orang-orang yang berasal dari wilayah tertentu sesuai dengan nama awisan tersebut. Menurut keterangan kuncen, awisan tersebut merupakan "ciri", yang sebenarnya tidak boleh digunakan walaupun orang tersebut berasal dari daerah sesuai nama awisan-nya. Apalagi awisan Arab yang letaknya di sebelah rumah kuncen. Sementara itu beberapa tanah awisan seperti awisan Sumedang, lahannya banyak dipakai untuk tanah pertanian dan kolam-kolam ikan.

c. Tanah garapan, yaitu wilayah yang digunakan sebagai lahan garapan warga, misalkan dengan dibuat huma, sawah. Oleh warga Kampung Dukuh tanah garapan ini digunakan sebagai kebun, kolam ikan dan juga untuk ditanami pohon-pohon besar seperti albasiah dan jati.

d. Tanah tutupan, yaitu kawasan hutan yang tertutup untuk digunakan dan dieksploitasi, karena apabila diganggu 
akan dikenai sanksi hukum oleh yang memilikinya, dalam hal ini pemerintah atau negara.

e. Tanah cadangan, yaitu wilayah yang diperuntukkan bagi lahan pemukiman warga. Lahan cadangan ini sampai saat ini menjadi polemik di antara warga Kampung Dukuh yang menganggap tanah ini bagian dari mereka, dengan pemerintah yang menjadikan lahan ini sebagai hutan jati di bawah pengawasan Departemen Kehutanan.

Mata pencaharian hidup penduduk Dukuh yang utama adalah bertani. Bentuk pertanian yang dilakukan ialah berladang (kebun) dan lahan basah (sawah). Adapun mata pencaharian lainnya ialah beternak ayam, domba, kerbau, dan memelihara beberapa jenis ikan di balong (kolam) Warga Kampung Dukuh yang bermigrasi ke daerah lain beserta keturunannya, serta ada yang menjadi pedagang, pengajar, dan lain sebagainya. Mereka tidak ada yang menjadi pegawai negeri karena hal ini sangatlah dilarang. Menurut kuncen Dukuh, larangan ini berhubungan dengan pengalaman Syekh Abdul Jalil sewaktu di Sumedang yang memandang para pejabat pemerintahan, baik bupati beserta para pembantunya telah melanggar agama Islam.

Kendatipun seluruh warga masyarakat Kampung Dukuh secara formal memeluk agama Islam, tetapi dalam praktik keseharian banyak unsur-unsur tradisi yang mewarnai kehidupan keagamaan mereka. Berbagai jenis upacara tradisional masih dilaksanakan oleh mereka. Beberapa upacara tradisional yang secara rutin dilaksanakan oleh masyarakat Kampung Dukuh, antara lain:

- Ngahaturankeun tuang,yaitu kegiatan yang dilakukan masyarakat Kampung Dukuh atau pengunjung yang berasal dari luar apabila memiliki keinginankeinginan tertentu seperti kelancaran dalam usaha, perkawinan, jodoh, dengan cara memberikan bahan makanan berupa garam, kelapa, telur, ayam, kambing atau hewan lainnya sesuai dengan kemampuan.

- Nyanggakeun, merupakan salah satu kegiatan penyerahan sebagian hasil pertanian kepada kuncen untuk diberkahi. Masyarakat tidak diperbolehkan memakan hasil panennya sebelum melakukan kegiatan ini.

- Tilo Waktos, merupakan kegiatan yang dilakukan oleh kuncen, pemberian doa oleh kuncen terhadap makanan yang akan dihidangkan untuk merayakan hari besar Islam 1 Syawal, 10 Rayagung, 12 Maulud, 10 Muharam.

- Manuja, adalah penyerahan bahan makanan dari hasil bumi kepada kuncen untuk diberkati. Bahan makanan ini untuk hidangan di hari raya Idul Fitri dan Idul Adha.

- Maros, yaitu menyerahkan sebagian hasil bumi yang dimiliki kepada aparat pemerintahan, seperti lurah dan camat.

- Cebor Opat Puluh, adalah mandi di jamban umum dengan empat puluh kali siraman, menggunakan air khusus yang telah diberi doa-doa oleh kuncen.

- Jaroh, yaitu berziarah ke makam Syekh Abdul Jalil, dengan ketentuan: sebelumnya harus mandi cebor opatpuluh, mengambil air wudhu, menanggalkan semua perhiasan serta tidak menggunakan pakaian yang bercorak, dan tidak memakai pakaian dalam.

- Shalawatan, dilakukan pada hari Jumat di rumah kuncen dengan membaca Shalawatan Karmilah sebanyak 4.444 kali.

\section{Sejarah Kampung Dukuh}

Sejarah Kampung Dukuh terdapat dalam tulisan berbahasa Arab yang dipegang oleh kuncen. Asal mula Kampung Dukuh berawal dari keadaan Sumedang pada abad ke-17. Pada saat itu Sumedang berada di bawah kekuasaan 
Mataram, bupatinya yang bernama Rangga Gempol II. Pada suatu hari, Rangga Gempol II menghadap Sultan Mataram untuk melapor atas meninggalnya Penghulu Agama Islam di Sumedang. Rangga Gempol II memohon kepada Sultan Mataram agar menunjuk seorang penghulu agama Islam untuk ditempatkan di Sumedang. Sultan Mataram mengatakan bahwa orang yang akan menjadi penghulu di Sumedang tidak usah dicari jauh-jauh karena orang tersebut ada di pedesaan Pasundan. Rangga Gempol II kemudian mencari orang yang dimaksud oleh Sultan Mataram sampai akhirnya ia bertemu dengan Syekh Abdul Jalil, pemimpin sebuah pesantren.

Setelah melalui perundingan, Syekh Abdul Jalil bersedia menjadi penghulu, dengan mengajukan sebuah syarat kepada Rangga Gempol II. Syarat tersebut adalah entong ngarempak syara, yang artinya jangan melanggar syara atau hukum agama Islam, seperti: membunuh, merampok, mencuri, berzinah dan lain-lain. Bila syarat tersebut tidak dipenuhi selama Syekh Abdul Jalil menjabat sebagai penghulu, maka ia akan mengundurkan diri dari jabatan tersebut.

Selama dua belas tahun Syekh Abdul jalil menjadi penghulu agama di Sumedang. Hukum syara yang menjadi acuan tersebut berjalan sebagaimana mestinya. Dapat dikatakan, Sumedang ketika itu sangatlah damai dan tentram, baik di dalam masyarakat Sumedang sendiri, maupun dalam hubungannya dengan kerajaan atau kesultanan lainnya.

Suatu ketika Syekh Abdul Jalil pergi ke Mekkah untuk menunaikan ibadah haji. Pada saat itu pula terjadi pembunuhan terhadap utusan dari Kerajaan Banten. Setelah kembali dari Mekkah, ia mengetahui bahwa ada peristiwa pembunuhan tersebut, dan mayatnya dibuang ke hutan atas perintah Rangga Gempol II agar tidak diketahui oleh matamata Banten, khususnya Syekh Abdul Jalil.
Mengetahui kejadian tersebut, Syekh Abdul Jalil pun lalu mengundurkan diri dari jabatannya sebagai penghulu, walaupun Rangga Gempol II bersikeras menolak pengunduran diri Syekh Abdul Jalil. Syekh Abdul Jalil beserta keluarganya kemudian pergi dari Sumedang dan tidak kembali lagi ke tempat pesantren yang dipimpinnya. Semenjak itu, dia berpindah-pindah dari satu tempat ke tempat lain. Setiap kali di tempat yang baru, ia selalu melakukan tafakur (selalu mengingat Allah SWT dengan segala ciptaan-Nya di dunia ini), memohon petunjuk Allah untuk mendapatkan tempat yang cocok dalam menjalankan ajaran agama Islam.

Pada tanggal 12 Maulud tahun Alif (tidak ada keterangan yang pasti mengenai tahun yang tepat), ketika selesai melakukan tafakur di daerah Tonjong (masuk dalam kawasan Garut), ia mendapat penglihatan berupa sinar sagede galuguran kawung (sebesar pohon aren) yang bergerak menuju arah tertentu. Sinar tersebut diikuti oleh Syekh Abdul Jalil. Akhirnya, ia berhenti di suatu daerah yang terletak di antara Sungai Cimangke dan Cipasarangan. Daerah tersebut ternyata telah dihuni oleh pa kebon dan ni kebon, yang bernama Aki Candradiwangsa dan istrinya, Nini Candradiwangsa. Kedua orang ini adalah yang mengolah dan menjaga ladang. Aki dan Nini Candradiwangsa menerima Syekh Abdul Jalil beserta keluarganya dan diperbolehkan tinggal di rumah mereka (sekarang dinamakan bumi lebet). Aki dan Nini Candradiwangsa kembali ke daerah asalnya di Cidamar (Cidaun yang terletak di Cianjur Selatan). Rumah beserta lahan yang telah mereka tanami diberikan kepada Syekh Abdul Jalil.

Dalam perjalanan pulang, Aki dan Nini Candradiwangsa meninggal dunia. Tempat mereka meninggal itu sampai sekarang disebut Palawah Candra Pamulang, berupa kulah (lubuk) di sebuah wahangan (sungai kecil) yang terletak di daerah Cianjur Selatan. 
Istilah dukuh yang berarti duduk, berasal dari kata padukuhan, yang artinya sama dengan pacalikan yang berarti tempat bermukim. Namun ada juga yang mengartikan dukuh dengan teguh, kukuh, patuh, dan tukuh, yang bermakna kuat, tegas, dan teguh dalam mempertahankan kebenaran dan apa yang diamanatkan oleh karuhun (leluhur).

\section{Pola Perkampungan}

Keberadaan kampung adat biasanya dicirikan dari bentuk rumah dan pola perkampungannya. Oleh karena itu, suatu kampung adat dapat dengan mudah dikenali secara kasat mata. Dari kejauhan saja sudah nampak deretan rumah yang teratur dan bentuknya seragam. Rumahrumah di perkampungan adat biasanya berbentuk rumah panggung dengan bahan material terbuat dari kayu, bambu, dan beberapa kampung adat di antaranya menggunakan atap dari daun rumbia dan ijuk. Selain itu, di lingkungan kampung adat juga menampakkan suasana yang tenang dan penuh kesahajaan.

Ditinjau dari pola perkampungan, hampir setiap kampung adat pada bagian luarnya dipagari, baik dengan tanaman maupun pagar bambu. Sementara di belakang pagar, terdapat kandang-kandang hewan ternak dan tempat mandi, mencuci, dan kakus (MCK). Semakin ke dalam, barulah tampak rumah-rumah yang menjadi tempat bermukim penduduk setempat. Deretan rumah-rumah tinggal ini ditata secara rapi dan teratur menurut ketentuan adat. Di tengah-tengah perkampungan terdapat sebidang tanah lapang. Tidak jauh dari tanah lapang terdapat sebuah bangunan yang cukup luas, yang menjadi tempat pertemuan bagi masyarakat penghuni kampung adat. Selain itu juga terdapat sebuah masjid atau tempat peribadatan. Satu hal yang menjadi ciri khas kampung adat, biasanya di sekitar kampung tersebut terdapat sebuah kawasan hutan larangan dan makam yang dikeramatkan. Makam ini dipercaya oleh masyarakat setempat sebagai makam leluhur mereka. Oleh karena itu, makam ini biasanya dikeramatkan.

Kampung Dukuh Dalam merupakan suatu kesatuan pemukiman yang mengelompok, terdiri atas beberapa puluh rumah yang tersusun pada kemiringan tanah yang bertingkat. Pada setiap tingkatan terdapat sederetan rumah yang membujur dari barat ke timur. Letak antarrumah hampir berdempetan, sehingga jalan kampung terletak di sela-sela rumah penduduk. Sebidang tanah lapang berukuran $\pm 10 \times 15$ meter terletak di sebelah bawah Dukuh Dalam. Lapangan ini biasa digunakan sebagai tempat menjemur padi.

Pada saat penelitian ini dilakukan, di dalam kawasan Kampung Dukuh Dalam terdapat 32 buah rumah, sebuah masjid, dan sebuah bangunan Bumi Alit. Di dalam Bumi Alit ini tersimpan benda-benda pusaka. Bumi Alit pun sekaligus menjadi tempat tinggal kuncen. Sementara itu di Dukuh Luar terdapat 90 buah rumah, 1 masjid, 17 MCK (mandi cuci kakus) pribadi, 14 MCK umum, 7 buah sumur, dan 1 bangunan Departemen Sosial (Depsos), yang berfungsi sebagai sarana pengobatan (puskesmas).

Sebelum terjadi peristiwa kebakaran yang membumihanguskan kawasan Kampung Dukuh Dalam pada tahun 2010, jumlah bangunan dan luas wilayah Kampung Dukuh Dalam tidak pernah berubah, yaitu sebanyak 40 rumah. Pembatasan jumlah ini bukan karena keharusan adat, melainkan karena faktor keterbatasan lahan. Di Kampung Dukuh Dalam, rumah diwariskan secara turun temurun.

Seseorang yang telah menikah dan memutuskan untuk hidup berpisah dari orang tuanya dapat tinggal atau membuat rumah di wilayah Kampung Dukuh Luar atau di luar wilayah Kampung Dukuh. Akan tetapi apabila orang tua meninggal dan mewariskan rumahnya di Kampung Dukuh Dalam kepada anaknya, maka anak tersebut boleh kembali menetap di wilayah Kampung Dukuh Dalam. 
Kepemilikan lahan di Kampung Dukuh memang keseluruhan merupakan bagian dari tanah adat, tetapi individuindividu mempunyai hak atas kepemilikan tanah mereka masing-masing. Hal itu dibuktikan dengan adanya beban pajak yang harus ditanggung warga Kampung Dukuh atas kepemilikan lahan, kecuali Kampung Dukuh Dalam tidak dikenai pajak. Jual beli lahan bisa dilakukan tetapi harus dijual kepada sesama warga Kampung Dukuh. Hal itu guna menghindari jatuhnya kepemilikan lahan kepada orang luar.

\section{Arsitektur Rumah Kampung Dukuh}

Pengertian arsitektur tradisional secara awam biasanya mengacu pada bentuk-bentuk rumah adat, bangunanbangunan seperti rumah tinggal, balai, lumbung, dan bangunan lain yang dibuat oleh dan dalam lingkungan kelompok masyarakat dengan adat istiadat tertentu.

Budihardjo (1987:8) mengatakan bahwa tata ruang spasial dan bentuk fisik arsitektur tradisional selalu mengacu pada aspek non-fisik, seperti adat, kepercayaan, dan agama. Arsitektur tradisional juga berpaling pada komponen alami seperti gunung dan laut, serta flora dan fauna. Karya arsitektur tradisional pun sangat akrab menyatu dengan lingkungan alam dan manusia penghuninya. Setiap karya arsitektur tradisional selalu berusaha menyerasikan diri dengan sekitar, sesuai dengan tatakrama menempatkan diri, atas dasar sumbu religi atau sumbu bumi (axis mundi). Semua hal tersebut dalam rangka suatu tujuan yang mengacu pada keselarasan kosmis menuju situasi dan kondisi yang serba menenteramkan, menyejahterakan, dan membahagiakan manusia. Pengejawantahan konsep di atas muncul dalam bentuk keunikan-keunikan pada setiap karya rumah tradisional di Nusantara (Cecep, 2010:74).

Bentuk arsitektur dan keseragaman struktur bangunan pemukiman di kawasan Dukuh Dalam menjadi sesuatu yang unik. Rumah-rumah tersusun pada kemiringan tanah yang bertingkat membujur dari Barat ke Timur. Warga Kampung Dukuh, khususnya Dukuh Dalam, sangat menjunjung keharmonisan dan keselarasan hidup bermasyarakat. Idealisme itu berpengaruh pada bentuk bangunan di Kampung Dukuh yang tidak membolehkan penggunaan dinding dari tembok dan atap dari genteng serta jendela dari kaca. Hal itu dilandasi alasan bahwa hal yang bersifat kemewahan akan mengganggu kerukunan dan keharmonisan masyarakat.

\section{Aturan-aturan Adat Membangun Rumah}

Sejak ratusan bahkan ribuan tahun yang lalu, nenek moyang bangsa Indonesia telah memiliki sistem pengetahuan yang sangat kaya, mulai dari sistem astronomi, perhitungan tanggal, cara bercocok tanam dan pengetahuan yang lain. Demikian pula halnya dengan masyarakat Kampung Dukuh. Masyarakat Kampung Dukuh memiliki aturan-aturan adat berkaitan dengan tradisi membangun rumah, antara lain: rumah harus berbentuk rumah panggung, dinding bilik, dan lantai palupuh, dengan bahan-bahan bangunan yang terdapat di sekeliling mereka. Dilihat dari fisik bangunannya, rumah-rumah di Kampung Dukuh memiliki karakter tersendiri, mulai dari bentuk, tata letak dan bahan yang digunakan, terlihat seragam dengan kesan sederhananya.

Beberapa aturan adat di Kampung Dukuh Dalam dalam hal membangun rumah adalah:

\section{a. Bahan Bangunan}

Penggunaan bahan bangunan rumah di Kampung Dukuh Dalam merujuk pada kesederhanaan dan keharmonisan masyarakat. Hal ini juga dimaksudkan sebagai salah satu upaya menghindari timbulnya konflik sosial yang dipicu oleh"pamer kekayaan".

Ada beberapa ketentuan terkait bahan bangunan rumah yang harus digunakan dan yang tidak boleh digunakan. Bahan-bahan bangunan yang harus digunakan adalah: tiang-tiang rumah 
yang terbuat dari kayu, bilik sebagai dinding, palupuh (bambu yang di pipihkan) untuk lantai, eurih (alang-alang yang disusun atau diikat) atau ijuk sebagai atap, dan batu tatapakan (tempat berdirinya tiang-tiang utama). Bahanbahan bangunan, seperti kayu, bambu, dan eurih diperoleh di lingkungan sekitar pemukiman mereka. Pengumpulannya dilakukan secara gotong royong dengan para tetangga. Bahan-bahan yang tidak tersedia di hutan, mereka beli di toko bahan bangunan. Adapun bahan-bahan bangunan yang tidak boleh digunakan adalah genteng, tembok, lantai marmer atau keramik, kaca, dan cat atau kapur.

Namun ada beberapa kendala dalam memeroleh bahan-bahan bangunan ini, yaitu adanya penguasaan dari pihak pemerintah terhadap beberapa kawasan hutan yang dikelola oleh Perum Perhutani. Adanya penguasaan dari pihak Perum Perhutani ini menghilangkan akses masyarakat Kampung Dukuh untuk memeroleh bahan-bahan bangunan dari hutan.

\section{b. Proses Pembuatan Rumah}

Rumah menurut masyarakat Kampung Dukuh merupakan "pakaian" yang keberadaannya bisa mencerminkan keadaan keluarga yang menghuninya. Rumah yang baik adalah yang sederhana dan tidak melebihi rumah tetangganya. Oleh karena itu, sebelum seseorang mendirikan rumah di Dukuh Dalam, terlebih dahulu ia harus merundingkan dengan kerabatnya, sesepuh kampung, dan meminta izin kepada kuncen. Proses ini oleh masyarakat setempat disebut nguningakeun (Toto Sucipto, 1990: 165166).

Proses pembangunan rumah di Kampung Dukuh dapat dibagi ke dalam 2 tahap, yaitu:

1) Tahap persiapan, meliputi

kegiatan-kegiatan:

- Nguningakeun ka mama, yaitu meminta izin kepada kuncen untuk membangun rumah di Kampung

Dukuh.

- Menentukan lahan; lahan yang digunakan untuk rumah bisa berasal dari orang tua atau membeli di kawasan Dukuh Luar dan Bangkelung. Apabila lahan di Dukuh Dalam sudah penuh maka harus mencari lahan di kawasan Dukuh Luar atau Bangkelung.

- Kukumpul, yaitu mengumpulkan bahan bangunan berupa kayu, bambu, ijuk, tepus, dan batu untuk tatapakan. Bahan-bahan ini dikumpulkan secara berangsur-angsur 3-4 bulan sebelum mendirikan rumah. Bahan bangunan ini diperoleh di kawasan sekitar Kampung Dukuh. Wilayah-wilayah tersebut adalah tanah awisan Sumedang dan juga di wilayah yang disebut tanah cadangan serta tanah garapan. Bahan-bahan ini dikumpulkan melalui kegiatan gotong royong.

- Menentukan hari baik; perhitungan hari baik dilihat dari apesan, wedal, larangan sasih, dan menghindari hari dan bulan yang dianggap kurang baik, yaitu hari Rabu, Minggu, dan Bulan Sapar sampai dengan lebaran Mulud (bulan ke-2 sampai tanggal 14 bulan ke -3 tahu Hijriah).

2) Tahap Pelaksanaan Pembangunan, terdiri atas kegiatan-kegiatan:

- Ngalelemah, yaitu meratakan tanah dan menebangi pepohonan yang menghalangi tempat dimana akan didirikannya rumah. Oleh karena taneuh karomah berkontur miring, maka sebelum meratakan tanah, terlebih dahulu dibuat sengkedan (semacam fondasi) dari batu-batu besar. Fungsinya adalah untuk menahan tanah agar tidak longsor.

- Mengolah bahan; kayu yang sudah terkumpul dipotong-potong sesuai kebutuhan, kemudian dihaluskan dengan cara disugu (diserut). Sementara itu, alang-alang dan ijuk dirangkai untuk bahan atapnya. 
- Ngadegkeun, yaitu mendirikan rumah melalui kegiatan-kegiatan: memasang tatapakan, memancangkan tiang-tiang utama dan tiang-tiang penyangga, pemasangan dinding menggunakan bilik, pemasangan palupuh (lantai dari bambu), dan pemasangan atap dari ijuk. Semua proses pengerjaan dilakukan secara bergotong royong, yang punya rumah hanya menyediakan makan dan minum. Akan tetapi di Kampung Dukuh Luar, proses pengerjaan sudah ada yang menggunakan tenaga tukang. Tukang berasal dari kampung Dukuh sendiri. Ketika penelitian ini dilakukan, di Kampung Dukuh terdapat 5 orang tukang bangunan.

Tata ruang rumah terdiri atas: tepas (ruang depan), tengah imah (ruang tengah), enggon (kamar tidur), pawon atau dapur, dan goah yaitu ruang tempat menyimpan beras. Tepas (ruang depan) berfungsi sebagai ruangan untuk menerima tamu. Selain berfungsi sebagai ruang tamu, tepas juga berfungsi sebagai ruang keluarga apabila tidak ada tamu.

\section{c. Upacara-upacara}

Salah satu unsur budaya yang sifatnya universal, dan terdapat pada hampir semua kebudayaan suku-suku bangsa di Indonesia adalah upacara tradisional. Menurut S. Budhisantoso, 1990: 7, upacara tradisional adalah tingkah laku resmi yang dibakukan untuk peristiwa-peristiwa yang tidak ditujukan pada kegiatan teknis sehari-hari, tetapi mempunyai kaitan dengan kepercayaan akan adanya kekuatan di luar kemampuan manusia atau kekuatan supernatural, seperti roh nenek moyang pendiri desa, roh leluhur yang dianggap masih memberikan perlindungan kepada keturunannya, dan sebagainya. Upacara tradisional merupakan kelakuan atau tindakan simbolis manusia sehubungan dengan kepercayaan yang mempunyai maksud dan tujuan untuk menghindarkan diri dari gangguan roh-roh jahat.

Merujuk pada pengertian di atas dapat disimpulkan bahwa upacara adat tradisional merupakan suatu bentuk tradisi yang bersifat turun-temurun yang dilaksanakan secara teratur dan tertib menuru tadat kebiasaan masyarakat dalam bentuk suatu permohonan, atau sebagai ungkapan rasa terimakasih.

Dalam konteks tradisi membangun rumah di Kampung Dukuh, didapati kenyataan bahwa hampir semua tahap dalam proses pembangunan rumah senantiasa diawali dengan pelaksanaan upacara. Paling tidak, terdapat tiga kegiatan upacara yang harus dilakukan oleh warga Kampung Dukuh dalam rangkaian pendirian rumah, yaitu: upacara ngalelemah (meratakan tanah), ngadegkeun (mendirikan bangunan), dan ngalebetan bumi (mengisi rumah).

- Upacara ngalelemah dilakukan sebelum pelaksanaan kegiatan meratakan tanah, yang maksudnya adalah untuk meminta berkah kepada Yang Maha Kuasa dan memohon izin kepada para karuhun (leluhur) agar pelaksanaan pembangunan rumah berjalan dengan lancar.

- Upacara ngadegkeun (mendirikan bangunan) dilaksanakan pada saat memasang suhunan (atap). Tujuan upacara ini adalah minta berkah keselamatan agar rumah bisa dijadikan tempat bernaung dan memberikan keselamatan bagi keluarga yang akan menghuninya.

- Upacara ngalebetan bumi (mengisi atau menghuni rumah), dilaksanakan setelah rumah selesai dibangun dan akan dihuni. Tujuan upacara ini adalah agar keluarga yang menghuni rumah memeroleh keselamatan dan kesejahteraan, dijauhkan dari segala gangguan dan marabahaya.

\section{d. Pantangan-pantangan}

Kampung Dukuh mempunyai aturan tersendiri dalam membangun rumah. 
Selain beberapa ritual yang harus dilaksanakan, juga terdapat beberapa pantangan adat yang apabila dilanggar akan menimbulkan sanksi. Pantanganpantangan tersebut di antaranya:

- Rumah yang didirikan harus seragam dengan rumah-rumah tetangga di sekitarnya, tidak boleh lebih bagus atau megah, ini dimaksudkan untuk menghindari timbulnya rasa iri di antara sesama warga masyarakat.

- Rumah tidak boleh menggunakan dinding tembok, genteng, papan kayu, kaca, serta ubin keramik, karena bahanbahan tersebut dianggap mewah dan jauh dari kesederhanaan.

- Tidak boleh memasang kayu secara terbalik, yaitu ujung ada di bawah dan pangkal ada di atas. Pantangan ini mengandung makna simbolis, bahwa dalam hidup kita harus menempatkan sesuatu pada tempatnya, tidak boleh mengacaukan segala sesuatu yang sudah berjalan menurut kodratnya.

- Pintu rumah tidak boleh menghadap utara, karena pada arah utara terdapat areal karomah "keramat", sehingga jika orang masuk ke rumah dia akan membelakangi karomah.

- Tidak boleh menggunakan daun jendela lebih dari satu, dan jendela pun tidak boleh menggunakan kaca.

- Tembok tidak boleh dicat atau dikapur.

- Tidak boleh menghias rumah atau memajang hiasan dinding kecuali tulisan Arab. Pantangan ini mengandung pepatah bahwa apabila seseorang disibukkan dengan keinginan untuk menghias maka dia akan melupakan kewajiban ibadahnya.

- Lantai harus menggunakan palupuh (bilah-bilah bambu tipis memanjang), dan tidak boleh menggunakan kayu, apalagi ubin.

- Tidak boleh membangun atau mendirikan rumah pada hari Rabu karena menurut perhitungan masyarakat Dukuh, Rabu merupakan hari naas/sial untuk mendirikan rumah. Demikian juga, tidak boleh membuat pagar pada hari Minggu.

- Di Kampung Dukuh juga tidak diperkenankan adanya listrik dan televisi serta radio. Alat makan yang digunakan harus terbuat dari bahan kayu, bambu, dan batok kelapa. Material tersebut dipercaya lebih memberikan manfaat ekonomis dan kesehatan, karena bahan tersebut tidak mudah hancur, serta lebih mudah menyerap kotoran.

\section{e. Pelanggaran dan Sanksi}

Biasanya di balik semua aturan, pantangan atau larangan, terdapat sanksi yang mengikutinya. Demikian pula pantangan-pantangan yang berlaku pada kalangan masyarakat Kampung Dukuh merupakan aturan adat yang apabila dilanggar akan menimbulkan sanksi. Koentjaraningrat (1983:11-12) mengklasifikasikan aturan-aturan adat dalam beberapa klasifikasi menurut tingkatannya, yakni:

1) Tingkat pertama adalah lapisan yang paling abstrak dan luas ruang lingkupnya. Tingkat ini adalah ide-ide yang mengkonsepsikan hal-hal yang paling bernilai dalam kehidupan masyarakat. Konsepsi-konsepsi serupa itu biasanya luas dan kabur; tetapi walaupun demikian, atau justru karena kabur dan tidak rasional, biasanya berakar dalam bagian emosional dari alam jiwa manusia. Tingkat ini disebut sebagai sistem nilai budaya.

2) Sistem norma, yaitu nilai-nilai budaya yang sudah terkait pada perananperanan tertentu dari manusia dalam masyarakat.

3) Sistem hukum (baik hukum adat maupun hukum tertulis). Hukum sudah jelas mengenai bermacam-macam sektor hidup yang sudah terang batasbatas ruang lingkupnya.

4) Aturan-aturan khusus yang mengatur aktivitas-aktivitas yang sangat jelas dan terbatas ruang lingkupnya dalam kehidupan masyarakat. Itulah sebabnya aturan-aturan khusus ini sangat konkret 
sifatnya dan banyak di antaranya terkait dalam sistem hukum.

Aturan-aturan khusus yang tergolong ke dalam hukum dapat dibagi lagi ke dalam hukum positif, yaitu hukum yang pelanggaran dan sanksinya dituangkan dalam bentuk tertulis, dan hukum adat atau aturan-aturan adat yang mengacu pada nilai-nilai dan norma-norma yang berlaku di dalam suatu kelompok masyarakat yang tidak tertulis.

Sementara itu di kalangan masyarakat Kampung Dukuh, pelanggaran terhadap aturan-aturan adat memuat sanksi adat yang sifatnya juga tidak tertulis. Sanksi ini bisa berupa hukuman fisik, sanksi sosial, ataupun sanksi dari kekuatan-kekuatan gaib. Sanksi sosial antara lain berupa cemoohan, dikucilkan atau diasingkan, bahkan dibuang dari komunitas masyarakatnya. Adapun sanksi yang melibatkan kekuatan-kekuatan gaib atau makhluk-makhluk gaib, seperti karuhun (arwah leluhur), dedemit, jin, hantu dan sebagainya, antara lain: bencana alam yang disebabkan oleh murkanya kekuatan gaib atas pelanggaran adat yang dilakukan oleh seorang warga komunitas, malapetaka, musibah, dan kesialan yang menimpa diri pelanggar. Sanksi atau musibah yang terjadi menurut kepercayaan masyarakat setempat biasanya berupa kematian mendadak, terkena penyakit aneh, buta, diserang serangga dalam jumlah yang banyak, dan hilang ingatan (tidak waras).

Dalam hal ini, yang bisa menetralkan sanksi-sanksi ini adalah kuncen. Pada batas-batas tertentu, warga Kampung Dukuh yang terkena sanksi masih diberi kesempatan untuk meminta maaf dan berjanji untuk tidak melanggar aturan lagi. Permohonan maaf disampaikan kepada seluruh warga Kampung Dukuh melalui kuncen yang akan dibahas dalam suatu musyawarah warga. Akan tetapi bila pelanggarannya tergolong ke dalam pelanggaran berat, maka ia akan dibuang dari komunitasnya, dan tidak boleh bermukim di kawasan Dukuh Dalam.

\section{Beberapa Perubahan}

Betapapun ketatnya aturan-aturan adat yang melindungi tradisi, namun perubahan zaman dan perkembangan kebutuhan manusia, serta meningkatnya jumlah populasi, ternyata mampu menembus benteng tradisi. Sesungguhnya, dalam berbagai situasi, warga Kampung Dukuh selalu berusaha taat pada tradisi yang diwarisi dari leluhurnya. Akan tetapi, tuntutan zaman serta kebutuhan, memaksa mereka untuk berbuat yang melanggar aturan adat, kendatipun dalam batas yang masih bisa dipahami. Kondisi ini mendorong terjadinya perubahan, sehingga beberapa bentuk perubahan pun tidak dapat dihindari, khususnya pada kalangan masyarakat Kampung Dukuh Luar.

Dalam kaitannya dengan tradisi membangun rumah, terdapat beberapa perubahan yang cukup signifikan, antara lain:

- Pemakaian kenteng 'genting' sebagai atap rumah menggantikan eurih, ijuk, alang-alang dan sirap. Alasan mereka karena bahan-bahan tersebut sekarang ini susah didapatkan. Penggunaan genteng ini hanya terjadi di kawasan Dukuh Luar, sedangkan di kawasan Dukuh Dalam hal ini tidak terjadi.

- Penggunaan papan kayu untuk lantai rumah, menggantikan palupuh (bambu yang dipipihkan). Banyak alasan yang mereka lontarkan di antaranya bahwa sekarang ini sudah susah mendapatkan palupuh, di samping memakai papan kayu dirasakan lebih nyaman karena lebih kuat dan awet.

- Pemakaian hiasan dinding; Ada ketentuan di kalangan masyarakat Kampung Dukuh untuk tidak memasang hiasan apa pun pada dinding kecuali tulisan Arab. Kini orang Dukuh Luar sudah mulai memasang hiasanhiasan dinding berupa foto maupun lukisan, bunga-bunga.

- Dalam hal penggunaan peralatan rumah tangga, kini orang Dukuh sudah banyak yang memakai lemari untuk wadah 
pakaian, dan ranjang. Padahal dulu hal itu dilarang.

Perubahan-perubahan yang terjadi lebih bersifat fisik, belum begitu merambah pada hal yang bersifat prinsip atau bagian intinya. Dalam hal ini Ralph Linton, sebagaimana dikutip oleh Koentjaraningrat (1990:97), menjelaskan konsep perbedaan antara bagian inti dari suatu kebudayaan (covert culture), dan bagian perwujudan lahirnya (overt culture). Bagian intinya adalah misalnya (1) sistem nilai-nilai budaya; (2) keyakinan-keyakinan keagamaan yang dianggap keramat; (3) beberapa adat yang sudah dipelajari sangat dini dalam proses sosialisasi individu warga masyarakat; dan (4) beberapa adat yang mempunyai fungsi yang terjaring luas dalam masyarakat. Sebaliknya, bagian lahir dari suatu kebudayaan adalah misalnya kebudayaan fisik, seperti alat-alat dan benda-benda yang berguna, tetapi juga ilmu pengetahuan, tata cara, gaya hidup, dan rekreasi yang berguna dan memberi kenyamanan. Adapun bagian dari suatu kebudayaan yang lambat berubahnya dan sulit diganti dengan unsur-unsur asing, adalah bagian covert culture

Demikian halnya perubahanperubahan yang terjadi pada kalangan masyarakat Kampung Dukuh terkait dengan tradisi membangun rumah, yang terjadi adalah perubahan pada bentuk fisiknya. Adapun aturan-aturan dasar seperti arah hadap rumah, tata ruang rumah, dan konsep-konsep abstrak di balik pembangunan rumah, seperti upacaraupacara adat masih tetap dipelihara. Begitu pula arsitektur rumah yang masih seragam dan masih memperlihatkan kesederhanaan menunjukkan bahwa falsafah kerukunan hidup bertetangga dan solidaritas sosial masih tetap dipegang teguh.

\section{Tradisi Membangun Rumah sebagai Wujud Kearifan Lokal}

Konsep kearifan lokal atau kearifan tradisional adalah pengetahuan yang khas milik suatu masyarakat atau budaya tertentu yang telah berkembang lama sebagai hasil dari proses hubungan timbalbalik antara masyarakat dengan lingkungannya. Jadi, kearifan lokal berakar dari sistem pengetahuan dan pengelolaan lokal atau tradisional. Oleh karena itu, konsep kearifan lokal atau tradisional mengakar pada tradisi masyarakat setempat.

Pengertian kearifan lokal dalam perbincangan ini adalah tradisi-tradisi masyarakat (upacara, cerita-cerita rakyat, pengetahuan lokal, tabu/pantangan adat), yang merupakan jawaban kreatif masyarakat terhadap situasi-situasi geografis, sosial, historis maupun budaya yang bersifat lokal. Termasuk di dalam pengertian ini adalah sikap, pandangan, dan kemampuan suatu masyarakat di dalam mengelola lingkungan hidupnya.

Tradisi itu sendiri diartikan sebagai kebiasaan yang diwariskan dari satu generasi ke generasi berikutnya secara turun-temurun. Sementara itu, Ahimsa dalam sebuah makalahnya (2007) mendefinisikan, tradisi sebagai sejumlah kepercayaan, pandangan atau praktik yang diwariskan dari generasi ke generasi tidak melalui tulisan (biasanya secara lisan atau lewat contoh tindakan), yang diterima oleh suatu masyarakat atau komunitas sehingga menjadi mapan dan mempunyai kekuatan seperti hukum. Definisi ini menunjukkan bahwa tradisi juga merupakan nilai budaya, karena di dalamnya terkandung patokan-patokan, petunjuk, pedoman, atau kriteria untuk menentukan baik - buruknya sesuatu yang dihadapi. Oleh karena itu, kearifan lokal sering juga disebut dengan istilah kearifan tradisional, yang artinya kearifan masyarakat yang berpijak pada tradisi, atau kearifan yang sudah menjadi tradisi. Kearifan lokal sendiri lebih menekankan pada sifat lokalitas.

Definisi kearifan lokal secara leksikal berasal dari dua kata, yang pertama arif yang dalam kamus besar bahasa Indonesia memiliki arti bijaksana, cerdik dan pandai; dan lokal yang memiliki 
arti setempat. Adapun secara istilah definisi kearifan lokal adalah kebiasaan suatu komunitas sosial yang dibuat sebagai tata nilai, sumber moral, yang dihargai oleh komunitas mereka (Abdul Majid,2011).

Masyarakat dengan kearifan lokalnya telah ada di dalam kehidupan manusia semenjak zaman dahulu. Kearifan tersebut merupakan perilaku positif manusia dalam berhubungan dengan alam dan lingkungan sekitarnya yang dapat bersumber dari nilai-nilai agama, adat istiadat, petuah nenek moyang atau budaya setempat yang terbangun secara alamiah dalam suatu komunitas masyarakat untuk beradaptasi dengan lingkungan di sekitarnya. Perilaku ini berkembang menjadi suatu kebudayaan di suatu daerah dan terus berkembang secara turuntemurun. Oleh karena hubungan yang dekat dengan lingkungan dan sumber daya alam, masyarakat lokal, tradisional, atau asli, melalui "uji coba" telah mengembangkan pemahaman terhadap sistem ekologi dimana mereka tinggal yang telah dianggap mempertahankan sumber daya alam, serta meninggalkan kegiatan-kegiatan yang dianggap merusak lingkungan (Mitchell, 2000).

Kearifan lokal terbentuk sebagai keunggulan budaya masyarakat setempat maupun kondisi geografis dalam arti luas. Meskipun bernilai lokal tetapi nilai yang terkandung di dalamnya dianggap sangat universal. Dengan demikian, sistem pengetahuan lokal masyarakat tersebut dapat diintegrasikan dalam analisis risiko lingkungan dan mitigasi bencana alam berlandaskan kajian ilmu pengetahuan atau pandangan etik (Johan, 2009).

Hubungan intensif masyarakat Kampung Dukuh dengan lingkungan alam, sosial, dan historisnya, telah memberikan pengalaman sekaligus pengetahuan caracara pemanfaatan lingkungan bagi kepentingan hidupnya. Berbagai tanaman yang tersedia di sekeliling mereka, seperti pohon enau, rerumputan dan bambu, dimanfaatkan oleh masyarakat setempat menjadi bahan bangunan. Masyarakat setempat memanfaatkan ijuk yang diperoleh dari pohon enau, dan eurih atau alang-alang diolah menjadi bahan atap rumah. Bambu diolah menjadi bilik untuk dinding rumah, tiang, dan palupuh (lantai rumah). Demikian pula pengalamanpengalaman spiritual telah melahirkan berbagai tradisi upacara dalam kaitannya dengan keselamatan rumah dan penghuninya, serta berbagai bentuk pantangan adat yang fungsinya adalah sebagai pengendali masyarakat.

\section{PENUTUP}

Manusia, lingkungan, dan kebudayaan adalah tiga subsistem yang membentuk ekosistem lingkungan. Ketiganya saling memengaruhi satu sama lain, dan terjalin hubungan fungsional. Kondisi lingkungan memberikan pengaruh terhadap kehidupan manusia. Demikian pula sebaliknya, keberadaan manusia memengaruhi kondisi lingkungan alamnya, yang kemudian menentukan arah perkembangan suatu kebudayaan. Fenomena lingkungan telah memberikan pengalaman dan membentuk pengetahuan bagi manusia yang kemudian berkembang menjadi kebudayaan. Dalam konsep ekologi kebudayaan, manusia merupakan salah satu subsistem dalam ekosistem lingkungan.

Sebagai makhluk hidup, manusia paling mampu beradaptasi dengan lingkungannya dan selalu berupaya untuk memanfaatkan sumber-sumber yang ada untuk menunjang kebutuhan hidupnya. Tidak terkecuali dengan masyarakat Kampung Dukuh yang secara antropologis tergolong ke dalam kelompok masyarakat adat dengan beberapa cirinya. Ciri utamanya adalah terpeliharanya tradisi yang diwarisi dari para leluhurnya. Termasuk dalam hal ini adalah tradisi membangun rumah yang hingga kini masih dipegang erat oleh masyarakat Kampung Dukuh.

Kondisi lingkungan alam dan pengalaman-pengalaman sejarah serta 
spiritual, telah memberikan pelajaran bagi masyarakat Kampung Dukuh untuk menggunakan dan memanfaatkan berbagai potensi lingkungan alam yang terdapat di sekelilingnya bagi kepentingan membangun pemukiman mereka. Pengetahuan ini diturunkan dari satu generasi kepada generasi berikutnya dan kemudian berkembang menjadi tradisi.

\section{DAFTAR SUMBER}

\section{Makalah}

Ahimsa Putra, Heddy Shri. 2007. "Peranan dan Fungsi Nilai Budaya dalam Kehidupan Manusia". Makalah : disampaikan pada Pelatihan Tenaga Teknis Peneliti Kebudayaan - Direktorat Jenderal NBSF - Jakarta.

Budhisantoso, Subur. 1990. Term of Reference Perekaman Upacara Tradisional. Jakarta. Depdikbud.

Bustami, Abdul Latif."Teknik Inventarisasi Kepercayaan Komunitas". Makalah disajikan pada Bimbingan Teknis Pemetaan Komunitas Adat yang diselenggarakan oleh Direktorat Jenderal Nilai Budaya, Seni, dan Film Kementerian Pariwisata dan Ekonomi Kreatif. Sumedang, 16 Nopember 2011.

Kartawinata, Ade Makmur. (2009). "Keberadaan Masyarakat Adat di Tengah Arus Modernisasi”. Makalah yang disampaikan dalam Workshop dan Festival Komunitas Adat, diselenggarakan oleh BPSNT Bandung.

\section{Buku}

Abdul Majid.2011.

Pendidikan Berbasis Ketuhanan. Bandung: CV Maulana Media Grafika.

Bagdan,R.C.\& Wilken,S.R. 1986. Qualitative Research for Educational and introduction to Theory and Method. London: Allyn \& Bacon Inc.

Budihardjo, Eko. 1987.
Percikan
Masalah
Arsitektur
Perumahan, Perkotaan. Yogyakarta: Gajah Mada University Press.

Eka Permana, R. Cecep. 2010.
Kearifan Lokal Masyarakat Baduy dalam Mitigasi Bencana. Jakarta: Penerbit Wedatama Widya Sastra.

Koentjaraningrat. 1983.

Kebudayaan Mentalitas dan

Pembangunan. Jakarta: Penerbit PT

Gramedia. 1990.

Pengantar Ilmu Antropologi. Cetakan ke8. Jakarta: PT Rineka Cipta.

Mitchell, Bruce, Bakti Setiawan, Dwita Rahmi. 2000.

Pengelolaan Sumberdaya dan Lingkungan. Yogyakarta: Gadjah Mada University Press.

Singarimbun, Masri. 1988.

Metode Penelitian Survei. Cetakan ke-9. Jakarta: LP3ES.

Sucipto, Toto. 1990.

Kampung Dukuh: Tinjauan Etnografis dan Arsitektur Tradisional Rumah. Skripsi. Fakultas Ilmu Sosial dan Ilmu Politik Universitas Padjadjaran Bandung.

\section{Surat Kabar}

Johan Iskandar,

"Mitigasi Bencana Lewat Kearifan Lokal", Kompas, 6 Oktober 2009.

\section{Sumber Intenet}

Kleden, Emil. "Hak Masyarakat Adat: Ketegangan Antara Kewajiban Negara dan Realitas Kebutuhan: Studi Kasus Kasepuhan Sirnaresmi dan Citorek", diakses dari http://www.scribd.com/doc/36105858/Rise t-Hak-Masyarakat-Adat-KasusKasepuhan-Naskah-Final tanggal 19 Agustus 2010. 